\title{
COVID-19 pandemi süreci ve intrapartum dönemde bakım
}

\author{
COVID-19 pandemic process and care in the intrapartum period
}

\author{
Esra ÇEVIK ${ }^{1}$
}

${ }^{1}$ Öğr. Gör. Dr., Balıkesir Üniversitesi, Sağlık Bilimleri Fakültesi, Ebelik Bölümü, Balıkesir, Türkiye .

Sorumlu Yazar: Esra Çevik, Öğr. Gör. Dr. Balıkesir Üniversitesi, Sağlık Bilimleri Fakültesi, Ebelik Bölümü, Balıkesir, Türkiye. E-mail:esracevik@outlook.com Telefon: +90 2662440010

Başvuru Tarihi: 24.11.2021 Kabul Tarihi: 29.11.2021 Yayınlanma Tarihi: 30.11.2021

Attf için: Esra Çevik COVID-19 Pandemi Süreci ve İntrapartum Dönemde Bakım,2021;5(3):164-169

\section{Öz}

Amaç: $\mathrm{Bu}$ çalışma, COVID-19 pandemi sürecinde intrapartum dönemde bakıma ilişkin güncel bilgilerinin gözden geçirilmesi amacıyla planlanmıştır. Gereç ve Yöntem: Bu çalışma genel bir derleme olup literatürün özetlenmesiyle yapılmıştır. Bulgular: Şiddetli akut solunum sendromuna neden olabilen küresel bir pandemi Coronavirüs hastalığının (COVID-19) yaşamın birçok alanına olduğu gibi sağlık hizmetlerine, doğum öncesi, doğum ve doğum sonrası sürece etkileri olmuştur. Özellikle anne ve yenidoğan sağ|ığı hizmetleri etkilenmiş, hizmet sunumunda nicel ve nitel farklılıklar meydana gelmiştir.Bu nedenle COVID-19 pandemisinde intrapartum dönemde bakım ile ilgili güncel önerilerin ele alınması gerekmektedir. İntrapartum dönemdeki kadınların hastaneye başvuru zamanları, hastanede enfeksiyondan korunma, bulaşın önlenmesi, enfekte bireylerin bakım hizmetlerinden faydalanması ve yönetimin sağlanması maternal ve fetal sağlığın korunması açısından önemlidir. İntrapartum dönemde gebenin COVID-19 ile enfekte ya da şüpheli kişilerle temasının azaltılması gibi koruyucu önlemlervirüsten korunmada temel yöntem olarak belirtilmektedir. İntrapartum dönemin etkin yönetilmesi gebelerin güvenli bir şekilde doğum yaptığı, yeni doğan bebeklerin ihtiyaçlarının karşılandığı güçlü ve koordineli sağılık sistemlerine bağlıdır. Bu dönemde etkin rol alan ebeler, hemşireler, kadın doğum uzmanları ve neonatologlar arasında güçlü bir iş birliği sağlanması gerekmektedir. Bu konuda oluşturulmuş Acil stratejik eylem planlarının olması, gebelerin uygun zamanda uygun bakıma erişebilmelerini sağlamaktadır. Sonuç: İntrapartum dönemde sunulan bakım maternal ve fetal sağlığın korunması açısından önemli olup, enfeksiyonun etkin kontrol ve yönetimi, sağlık personelinin ve gebenin uygun koruyucu ekipman kullanımının sağlanması ve izolasyon önlemlerinin alınması gerekmektedir.

Anahtar Kelimeler: doğum; COVID-19; pandemi; ebe

\section{ABSTRACT}

Aim: This study was planned to review current information on care in the intrapartum period during the COVID-19 pandemic.

Material and Method: This study is a general review and made by summarizing the literature. Result: A global pandemic Coronavirus disease (COVID-19), which can cause severe acute respiratory syndrome, has had effects on health services, prenatal, natal and postnatal processes, as well as many areas of life. Especially maternal and newborn health services were affected, and quantitative and qualitative differences occurred in service delivery. Therefore, current recommendations regarding care in the intrapartum period in the COVID-19 pandemic should be addressed. It is important for women in the intrapartum period to apply to the hospital, to prevent infection in the hospital, to prevent transmission, to benefit from the care services of infected individuals and to provide management for maternal and fetal health. Protective measures such as reducing the contact of pregnant women with people infected or suspected with COVID-19 during the intrapartum period are stated as the main method of protection from the virus. Effective management of the intrapartum period depends on strong and coordinated health systems where pregnant women deliver safely and the needs of newborn babies are met. A strong cooperation should be established between midwives, nurses, obstetricians and neonatologists, who play an active role in this period. Having emergency strategic action plans created in this regard ensures that pregnant women can access appropriate care at the appropriate time. Conclusion:The care provided during the intrapartum period is important for the protection of maternal and fetal health, and effective control and management of infection, the use of appropriate protective equipment by health personnel and pregnant women, and isolation measures are required.

Keywords: labor; COVID-19; pandemic; midwife 
Coronavirüs hastalığı, asemptomatik seyredebildiği gibi şiddetli akut solunum yolu semptomlarına da neden olabilen ve enfekte kişilerde ateş, kuru öksürük, nefes almada güçlük ve dispne gibi semptomların gözlendiği morbiditesi yüksek bir halk sağlığı sorunudur. (1-3) Gebeler de bu hastalık yönünden önemli risk gruplarından biri olup gebelikte COVID19'un mortalite hızının \%6 olduğu (4) ve semptomların gebe olmayan kişilerle benzer olduğu bilinmektedir. (5) Gebelikte geçirilen COVID-19 enfeksiyonunun preeklampsi, preterm eylem, sezaryen, yoğun bakım ihtiyacı, mekanik ventilasyona bağlanma ve ölüm gibi maternal etkileri göz önüne alındığında, doğum için hastaneye başvuran gebelerin virüsten korunması hem kendi sağlığı hem yenidoğanın sağlığı açısından oldukça önemlidir. (6) Bu nedenle, doğum sırasında ve sonrasında COVID-19'a karşı ekstra önlemlerin alınması, bebeğin ve sağlık çalışanlarının güvenliğini yönünden elzemdir. $(2,7)$

COVID-19 pandemisi ile birlikte anne ve yenidoğan sağlığı hizmetlerine erişimde güçlükler olması antepartum, intrapartum ve postpartum dönem maternal, fetal mortalite ve morbiditede artşlara neden olmaktadır. (8) COVID-19 pandemisi nedeniyle anne ve yenidoğan sağlık hizmetlerine erişimin azalmasının mortalite üzerindeki potansiyel etkisini tahmin eden Guttmacher Enstitüsü tarafindan yapılan çalışmada, gebelik ve yenidoğana yönelik sunulan sağlık hizmetleri kapsamında \%10'luk bir düşüşün, dünya genelinde ek 28.000 anne ölümü, 168.000 yenidoğan ölümü ve 1.745 .000 majör obstetrik komplikasyon ile sonuçlanabileceğini göstermektedir. (9) Bu açıdan pandemi döneminde antepartum, intrapartum ve postpartum dönemin yönetimi oldukça önemlidir.

Dünya Sağıık Örgütü (DSÖ), Hastalık Kontrol ve Önleme Merkezi (CDC), Uluslararası Jinekoloji ve Obstetrik Federasyonu (IFGO), Kraliyet Koleji Jinekolog ve Obstetrisyenler Birliği (RCOG) ve Amerikan Obstetri ve Jinekoloji Derneği (ACOG) intrapartum dönemde yönetim ile ilgili rehberler yayınlanmış, güvenli annelik hizmetleri kapsamında verilen danışmanlık hizmetlerinin tele-sağlık sistemiyle karşılanması, COVID-19'lu gebelerin takip ve yönetimi, intrapartum izlem, emzirme konularda önerilerde bulunmuşlardır. $(10,11)$

\section{Doğum Şekli}

COVID-19 pandemisi döneminde yapılan ilk çalışmaların çoğunda, doğum sırasında aktif hastalığı olan kadınlarda \%81.8'e varan yüksek bir sezaryen oranı olduğu belirtilmektedir. COVID-19 ile enfekte gebelerin vajinal doğumu güvenli bir şekilde gerçekleştirilebileceği, özellikle asemptomatik ve hafif semptom ile seyreden koronavirüs hastalarında maternal ve perinatal sonucun çok fazla olumsuz etkilenmediği yönündedir. $(5,12)$ COVID-19, obstetrik endikasyon olmadığı durumlarda sezaryen ile doğum için endikasyon olmayıp, (13) solunum sıkıntısı, şiddetli pnömoni ve solunum yetmezliği olan COVID19'lu kadınlarda, tercihen bölgesel anestezi altında sezaryen ile doğum tercih edilmelidir. (5) ACOG, tek başına influenza veya COVID-19 tanısı almış olmanın, doğumun erken gerçekleştirilmesi için endikasyon olmadığını belirtmektedir. (14) COVID-19 enfeksiyonunda yenidoğana doğum sonrası bulaş olmaması için, obstetrik veya maternal endikasyon olmadığı takdirde doğumun, mümkünse izolasyon süresi tamamlandıktan sonra gerçekleştirilmesi, her gebenin bireysel olarak değerlendirilmesi, gestasyonel hafta ve fetal iyilik hali, obstetrik endikasyonlara dikkate alınarak multidisipliner yaklaşımla karar verilmesi gerekmektedir. (15) Obstetrik endikasyonlar dışında yapılan sezaryen doğumlarda maternal morbidite riski arttran bir faktördür. (7) Sezaryen ile doğum, annenin klinik durumunda hızlı bozulma, akut organ yetmezliği, septik şok, gebe uterusa bağlı mekanik ventilasyonda zorluk ve fetal distres gelişmesi halinde uygun olacaktır. (15)

Doğum şekline gebe bireysel olarak değerlendirildikten sonra karar verilir ve doğum izole odalarda uygun kişisel koruyucu ekipman giymiş ekip tarafindan gerçekleştirilmesi gerekmektedir $(11,13)$. Doğum eylemi sırasında ve doğum sonrası dönemde hastaların mümkünse tek kişilik odalarda takip edilmesi, tek kişilik odaların da kapanabilen bir kapısı olması, ayrı banyosu, tuvaleti olması ve iyi havalandırılması gerekmektedir. (13)

COVID-19'dan şüphelenilen veya COVID-19 olduğu teyit edilen kadınlara bakan tüm personel, doğum ve sezaryen sırasında bu tür hastalarla ilgilenirken N95 maske, tulum, uzun galoş, gözlük veya uzun yüz siperi dahil olmak üzere tam kişisel koruyucu ekipman kullanma konusunda eğitilmelidir. $(16,17)$ Her doğumdan veya sezaryenden sonra, tüm oda ve tüm yüzeyler sodyum hipoklorit solüsyonu ile veya hastanenin politikasına göre dekontamine edilmeli, tüm çalışanlar, kişisel koruyucu ekipmanları uygun şekilde giymeli ve çıkarmalıdır. Kullanılmış kişisel koruyucu ekipman ve diğer kıyafetler hastanenin politikasına göre uygun şekilde çıkarılmalı, çalışanlar koruyucu ekipman ve giysi değişimi sonrası kendi kıyafetlerini giymeden önce temizlenmelidir. (5) İntrapartum dönemde COVID-19 vakalarında intrapartum bakım algoritması Şekil 1'de sunulmuştur.

\section{İntrapartum Dönem}

Hafif COVID-19 semptomları olan kadınların ve maternal veya fetal sağlığı ile ilgili herhangi bir riski saptanmayan gebelerin, latent fazda evde kalmaları ve kendilerini izole etmesi teşvik edilmelidir. (11) Gebelere doğum hakkında gerekli bilgi verilerek önerilerde bulunulması, COVID-19 semptomları hakkında bilgilendirilmeleri, endişeleri varsa rahatça iletişime geçmelerine yönelik imkan sağlanmalıdır. Ayrıca doğum üniteleri de dahil olmak üzere hastaneye kabul edilen gebeler, kabul sırasında COVID-19 testi önerilmektedir. (11) Ayrıca CDC, ACOG ve Sağlık Bakanlığı raporlarına göre gebelere, COVID-19 aşıları önerilmektedir. $(14,15,18)$ 


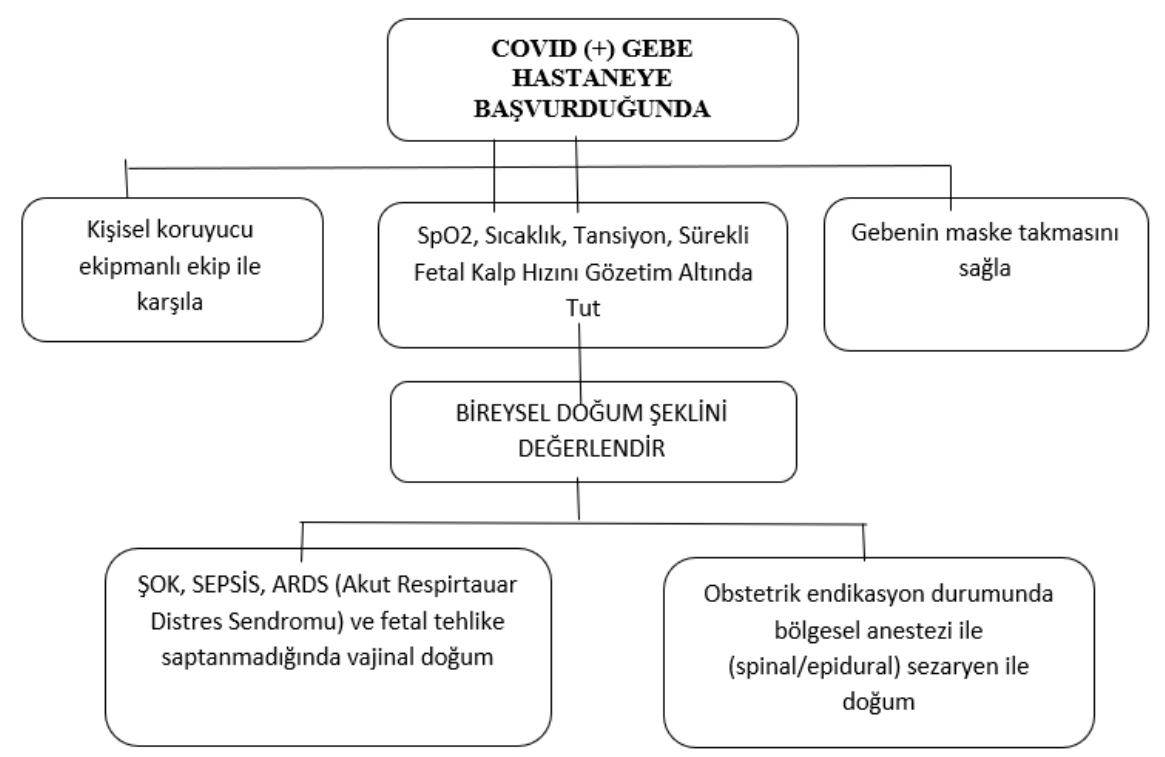

Şekil 1. COVID-19 vakalarında intrapartum bakım için algoritma (5).

CDC, tanı konmuş ya da şüpheli COVID-19'lu gebelerin, ekibin uygun enfeksiyon kontrol hazırlıkları yapabilmesi için hastaneye gelmeden önce obstetrik üniteyi bilgilendirmelerini önermektedir. (18) Tüm hastalar, doğum eylemine kabul için hastaneye girmeden önce COVID-19 semptomları açısından veya şüpheli kişilerle yakın temas içinde olup olmadıkları açısından taranmalıdır. $(6,13,18)$

Doğum ünitesine başvuru sırasında COVID-19 testi pozitif çıkan asemptomatik kadınlarda doğum sırasında kardiyotokografi kullanılarak sürekli elektronik fetal izleme önerilmemektedir. (10) COVID-19 testi pozitif çıkan kadınlara, rutin uygulamalara uygun olarak, kordonun gecikmeli klemplenmesi ve bebekleriyle ten tene teması önerilmelidir. $(11,12)$ Anne ile bebek arasında gecikmiş kordon klempleme ve ten tene temas uygulamasının yenidoğana SARS-CoV-2 bulaşmasını artırdığına dair hiçbir kanıt yoktur. (11) Semptomatik olduğundan şüphelenilen veya teyit edilen COVID-19 olan kadınlara, eğer maternal ve fetal herhangi bir risk yok ise kordonun gecikmeli klemplenmesi ve bebekleriyle ten tene teması (11), sürekli elektronik fetal monitorizasyon önerilmekte (10) ancak suda doğum önerilmemektedir. (12) Asemptomatik olan veya COVID-19 negatif olan kadınlar için suda doğum kontrendike değildir, sağlık personelinin kişisel koruyucu ekipmanları kullanması gerekir. Semptomatik COVID-19 enfekte kişilerde, öksürüğü, ateşi olan veya kendini iyi hissetmeyen kadınlar suda doğum yapmamalıdır. (11)

İntrapartum dönemde, refakatsiz doğumun gerçekleşmesinin birtakım sakıncaları bulunmaktadır. Öyle ki refakatsiz doğuma bağı ortaya çıkan olumsuz sağlık çıktıları sağlık kurumlarında COVID-19 bulaşmasının potansiyel risklerinden daha ağır bile olabilmektedir. (17) İntrapartum dönemde bakım alamama, refakat kısıtlamaları, indüksiyon dahil gereksiz müdahaleler, anne ve bebeğin ayrılması ve emzirmenin yasaklanması, kadınların doğumdaki haklarını tehdit etmektedir. (19) Özellikle refakat kısıtlamaları ile gebelerin destekleyici bakım uygulamalarından yoksun kalmalarının posttravmatik stres bozukluğu yaratabileceği belirtilmektedir. (20) Bu nedenle enfekte olmayan gebelerin yanında refakatçi alınmalıdır. Intrapartum süreçte gebe kadının refakatçisi asemptomatik olsa bile enfekte gibi kabul edilip, maske takması ve sıklıkla elini yıkaması gerektiği konusunda uyarılmalıdır. Refakatçi enfekte olduğu tespit edildiğinde kendini izole etmesi ve doğuma katılmaması, gebenin gerekirse kendine eşlik edecek bir kişi belirlemesi önerilmektedir. (11)

COVID-19 enfekte gebelerin doğum zamanlaması, hastalığın şiddetine, gebenin genel durumu, komorbiditelerin varlığı (preeklampsi, diyabet, kardiyak, hematolojik vb), gestasyonel hafta ve fetal iyilik hali dikkate alınarak multidisipliner yaklaşımla değerlendirilmeli, her gebe için doğum zamanlaması bireysel değerlendirme yapılarak karar verilmelidir (15). COVID-19 pozitif olan gebenin doğumu, anne ve yenidoğan yoğun bakım ünitesi olan üçüncü basamak sağlık merkezlerinde gerçekleştirilmelidir (5). COVID-19 pozitif olduğunda veya şüphelenilen gebeler hemen izole bir doğum odasına alınmalı (diğer hastalarla temastan kaçınarak) negatif basınçlı doğum odasına transfer edilmeli ve cerrahi maske takmaları sağlanmalıdır. COVID-19 enfekte gebenin yanında refakatçi kalmasına izin verilmemelidir. $(2,7,12)$

Bilindiği gibi doğum sırasında kadının, nabız, tansiyon, sıcaklık, oksijen satürasyonu gibi yaşamsal parametreleri her 3-4 saatte bir değerlendirilmesi gerekmektedir. Ayrıca SPO2 \%94'ün altına düşerse arteryel kan gazı alınarak PaO2 bakılmalı, oksijen desteği sağlanmalıdır. $(5,13)$ Yüksek ateşe sadece koronavirüs hastalığı ile ilgili bir bulgu olmayabilir, herhangi bir enfeksiyon olduğunda hastane protokolüne göre geniş spektrumlu antibiyotiklerle tedavi edilmelidir. $(5,13)$

Beslenme yönünden intrapartum dönemde kadına doğumun ilk evresinde ağızdan sıvı kısıtlaması önerilmezken, doğum eyleminde tolere edildiği ölçüde su, sıvı verilmesi önerilmektedir. Rejyonel anestezi uygulanmayan kadınlarda doğumun ilk evresinde dik pozisyonlar tavsiye edilmektedir. Anestezi uygulanmayan kadınlarda doğumun ilk evresinde doğum odasında yürümesi önerilmektedir. (13) Doğumda sürekli mesane kateterizasyonu önerilemez ve fistık topunun rutin kullanımı, yararlı olduğu gösterilmediği ve enfeksiyonu bulaştırmanın bir yolu olabileceği için doğumda önerilmemektedir. (13) Doğum eyleminin ikinci evresinin yönetimi aksi belirtilmedikçe değiştirilmemelidir. (3) Uygun obstetrik endikasyona 
göre eylem süresini kısaltmak amacıyla (balon, oksitosin) doğum eylemi indüksiyonu veya augmentasyonu yapılabilir. $(3,13)$ Epidural anestezi bu tür kadınlar için güvenlidir ve teşvik edilmekte olup enstrümantal doğum, kadın yorgunsa veya uzun süren ikinci evre için kullanılabilir. (5) Ortama aşırı aerosol yayılımının önlenmesi amacıyla aktif doğum eyleminin mümkün olan en kısa sürede tamamlanmaya çalışılmalıdır. Doğum eylemi ve doğum sırasında odada bulunacak sağık personeli sayısı mümkün olduğunca sınırlandırılmalıdır. (15)

\section{Doğum Odasının Yönetimi}

Dünya Sağılı Örgütü, COVID-19'un damlacık yoluyla bulaştğını ve enfekte bir kişiye uygun koruyucu ekipman olmadan bir metre mesafede maruz kalan personel, hastalığa yakalanma açısından son derece yüksek risk altında olduğunu belirtmektedir. (17) Doğumların izole negatif basınçlı odalarda, minimum personel sayısı ile gerçekleştirilmeli ve önlük, N95 solunum maskeleri, gözlük ve eldivenler dahil kişisel koruyucu ekipmanlar giymiş olmalıdır. Negatif basınçlı odaların yetersiz olduğu durumlarda, anneden iki metreden daha uzakta bulunan bir bebek ısıtıcısı ile bulunan bir doğum odası olmalıdır. (7) COVID-19 pozitif olduğundan şüphelenilen gebeler hemen izole bir doğum odasına (diğer hastalarla temastan kaçınarak) veya negatif basınçlı doğum odasına transfer edilmeli ve cerrahi maske takmaları sağlanmalıdır.COVID-19 pozitif gebe varlığında refakatçi izin verilmemelidir. Sadece son iki hafta içinde temas öyküsü ve klinik semptomu olmayan aile üyelerinin doğuma katılmasına izin verilir ve refakatçi aile üyelerinin de tek kullanımlık tıbbi maske takmaları zorunludur (15).

\section{Doğum Sonrası}

COVID-19'dan şüphelenilen veya COVID-19 olduğu teyit edilen anneler, uygun önlemlerle ten tene temasa, emzirmeye başlamaları ve emzirmeye devam etmeleri için teşvik edilmelidir. Virüs bazı anne sütü örneklerinde bulunmuş olsa da bu konuda veriler sınırlıdır ve anne sütü alımından bebeğe bulaşma riski belirsizdir. Yenidoğana damlacık geçişi, beslenme sırasında yakın temas yoluyla gerçekleşebilir. (15) Bu nedenle COVID-19'u doğrulanmış anneler ve COVID-19 şüphesi olan semptomatik anneler, emzirmeden önce el hijyeni yapmalı ve emzirme sırasında maske takmalıdır. (21) DSÖ, CDC ve RCOG emzirmeyi desteklemektedir. $(9,14,15)$ FIGO erken klemplemeyi önerirken, RCOG geç klemplemeyi önermektedir. $(5,7)$ Term yenidoğanlarda, viral geçişi azaltmak amacıyla geç kord klemplenmesinin yapılmaması önerilmektedir. Ancak bu konuda literatürde görüş birliği yoktur. (15)

Doğum sırasında COVID-19 olduğu bilinen hastalardan doğan bebekler, COVID-19 şüphesi olan bebekler olarak kabul edilmelidir. Bu nedenle, COVID-19 şüphesi olan bebekler, diğer sağlıklı bebeklerden izole edilmeli ve bakımı yapılmalıdır (14). Singapur'da SARS-CoV-2 ile enfekte olmuş 18 hastadan alınan numunelerde dışkıda COVID-19 virüsü tespit edildiği belirtilmektedir. (22) Bu nedenle COVID-19 pozitif anneden yenidoğana bulaşı önlemek için olası dışkılama durumunda uygun antiseptik temizliğin kişisel koruyucu ekipmanlar ile sağlanması yenidoğanın eylem sırasında virüs ile karşılaşmasını engellemek adına önemlidir. (6)

Literatüre bakıldığında COVID-19 pandemisinde emzirmenin güvenliği veya anne bebek ayrılması ile ilgili sınırlı sayıda çalışma olduğu görülmektedir. Bu çalışmalarda anneden solunum yolu ile yenidoğana enfeksiyon bulaşması kaygısıyla anne-bebek birlikteliğine ara verilmekte bu durum da hem anne hem de bebeğin sağlığını olumsuz etkilemektedir. Bu faktörler maternal stres, infant stresi, anne sütünün azalması, emzirme başarısının azalması, aile üyeleri ve refakatçilerin stresinin artması dolaylı olarak sağlık sistemine yük olarak karşımıza çıkmaktadır. (23) DSÖ, COVID-19 rehberinde kesintisiz olarak ten tene temasın ve emzirmenin teşvik edildiği ve birçok Avrupa Birliği (AB) ülkesinin bu yaklaşımı izlediği, yalnızca bebeğin yenidoğan yoğum bakımı gerektirdiği koşullarda anne ve bebek birlikteliğinin sınırlandığı görülmektedir. (16) Eğer anne klinik olarak ağır ya da kritik derecede hasta ise, anne bebek ayrımı en iyi seçenek olup, anne süt üretimini devam ettirmek için sağmaya devam edilmelidir. Anne klinik olarak stabil ise, temizlik ve maske kurallarına uyarak yenidoğanı emzirebilir. (15) Tablo 1'de COVID-19 pandemisinde annenin klinik tablosuna dayalı yenidoğan bakım önerileri sunulmuştur. Tablo 1. COVID-19 pandemisinde annenin klinik tablosuna dayalı yenidoğan bakım önerileri (24).

\begin{tabular}{|l|l|l|}
\hline Emzirme & $\begin{array}{l}\text { Mümkün olan en kısa sürede, tercihen } \\
\text { yaşamın ilk bir saatinde emzirmeye başlama }\end{array}$ & $\begin{array}{l}\text { Bulaşmayı önlemek için biyogüvenlik önlemlerini takiben } \\
\text { süt sağımı yoluyla emzirme. } \\
\text { Annenin hijyeni ve cerrahi maske kullanımı gibi önlemler } \\
\text { alındıktan sonra doğrudan emzirmeye izin verilmelidir. }\end{array}$ \\
\hline $\begin{array}{l}\text { Ten tene } \\
\text { temas }\end{array}$ & $\begin{array}{l}\text { Hipotermi riskini azaltmak ve emzirmeyi } \\
\text { desteklemek için doğumdan hemen sonra } \\
\text { stabil ve asemptomatik klinik koşullara sahip } \\
\text { olanlarda ten teması sağlanmalıdır. }\end{array}$ & $\begin{array}{l}\text { COVID-19'dan şüphelenildiğinde hemen ten tene temastan } \\
\text { kaçınılmalı ve ilk bakımın yapılması için anne-bebek ayrılması } \\
\text { tavsiye edilir; Annelerin vücut hijyeni ve kişisel koruyucu } \\
\text { ekipman değişiminden sonra erken ten tene temas önerilir. }\end{array}$ \\
\hline $\begin{array}{l}\text { Göbek } \\
\text { Kordonu } \\
\text { Klempleme } \\
\text { zamanı }\end{array}$ & $\begin{array}{l}\text { Yenidoğanlar sağlıklı koşullarda doğduysa, } \\
\text { doğumdan } 1 \text { ila } 3 \text { dakika sonra yapılabilir. }\end{array}$ & $\begin{array}{l}\text { Doğumda kas tonusu iyi ve solunumu yeterli olan } \\
\text { gestasyonel yaşta } \geq 34 \text { hafta ise klempleme zamanında } \\
\text { yapılabilir. Gebelik yaşı <34 hafta olan yenidoğanlarda göbek } \\
\text { kordonunu klemplemeden önce 30-60 saniye beklenmesi } \\
\text { endikedir. }\end{array}$ \\
\hline
\end{tabular}




\section{COVID-19 Pandemisinde İntrapartum Dönemde Ebenin Rolü}

Ebeler pandemi öncesinde olduğu gibi pandemide de anne bebek sağlığının korunup geliştirilmesinde kritik önemi olan, annelere ve bebeklere en yakın olan sağlık çalışanlarındandır. Pandemide refakat sınırlaması olduğu göz önünde bulundurulduğunda gebeye antepartum, intrapartum ve postpartum dönemde verdikleri bakımın önemi daha anlaşılır hale gelmiştir. Ebeler, gebelere kişisel koruyucu önlemlerin alınması sağlama konusunda eğitim verme ve gerekli ekipmanların temini sağlama, enfeksiyonun yayılma yolları ve anne ve bebeğe etkileri hakkında bilgi verme, tele-sağlık hizmetlerinin sunumu, COVID-19 ile enfekte ya da şüpheli kadınlarla negatif kadınların temasını önlemeye yönelik önlemlerin alınması, intrapartum dönemde doğum odasının düzenlenmesi, intrapartum dönemde anne ve bebeğin bakımını yapma ve gerektiğinde COVID-19 testi için gereken örnekleri alma, doğum eylemi sırasında kullanılan araç-gereçlerin ve ortamın uygun şekilde dezenfeksiyonunun/ strerilizasyonunun sağlanması ve kontrolü, postpartum dönemdeki kadın ve yenidoğanın bakımını yapma, sorumlu hekim ile birlikte kontrollerin planlanması ve takibi konusunda bakım ve hizmet sunmaktadır. (6)

Ebeler COVID-19 tanısı almış ya da şüpheli kadınlarda emzirmeye yönelik bilgi vermeli, bebeğin bakımına ve beslenmesine yardımcı olmalıdır. Ayrıca aşılı olmayan gebelerin COVID-19 aşısı hakkında bilgilendirerek bağışıklanmasına ön ayak olmalıdırlar. Enfeksiyon ile savaşım yönünden ellerin sık sık yıkanması da dahil olmak üzere rutin hijyen uygulamalarının sürdürülmesi, fiziksel mesafenin korunması ve diğer bireylerle teması mümkün olduğunca sınırlanması da dahil olmak üzere güvenlik önlemlerini uygulamaya devam edilmelidir. (14) Çalışma ortamında ziyaretçiler için kısıtlamalar düzenlenmeli ve sağlık çalışanlarının hasta odasına girişi sınırlandırılmalıdır. Ayrıca anne bebek sağlığını iyileştirmek için intrapartum dönemde kanıta dayalı uygulara dayalı destekleyici bakım sunulmalıdır. (25)

\section{SONUÇ}

Gebenin antepartum, intrapartum, postpartum dönemde sunulan bakım anne ve bebek sağığının korunup geliştirilmesi için önemli olup pandemiyle birlikte bu önem daha da artmıştır. Bu süreçte sağlık çalışanlarının özellikle ebelerin oynadığı rol oldukça önemli olup doğrudan anne ve bebek sağığına etkileri bulunmaktadır. COVID-19 enfeksiyonunun maternal ve fetal etkileri ile ilgili kesin kanıtlar henüz bulunmamakla birlikte, enfekte gebenin yakından takip edilmesi gerekmektedir. Intrapartum dönemde gebenin COVID-19 ile enfekte ya da şüpheli kişilerle temasının azaltıması gibi koruyucu önlemler virüsten korunmada temel yöntem olarak belirtilmektedir. İntrapartum dönemin yönetiminde annelerin güvenli bir şekilde doğum yapabilecekleri ve yeni doğan bebeklerin ihtiyaçlarının karşılandığı güçlü ve koordineli sağlık sistemlerine bağlıdır. Bu dönemde etkin rol alan ebeler, hemşireler, kadın doğum uzmanları ve neonatologlar arasında güçlü bir iş birliği sağlanması gerekmektedir. Bu konuda oluşturulmuş Acil stratejik eylem planlarının olması, gebelerin uygun zamanda uygun bakıma erişebilmelerini sağlamaktadır. COVID-19 pandemisinde intrapartum dönemde bakım uygulamalarının etkilerini belirlemek için kanıt düzeyi yüksek çalışmalara gereksinim duyulmaktadır.

\section{BILDIRIMLER}

Çıkar Çatışması: Yazarlar arasında çıkar çatışması yoktur.

Finansal Destek: Herhangi bir kurumdan maddi destek alınmamıştır.

Etik Kurul İzni: Çalışma derleme türünde bir çalışma olduğu için etik kurul izni alınmamıştır.

\section{KAYNAKLAR}

1. Lai C-C, Liu YH, Wang C-Y, Wang Y-H, Hsueh S-C, Yen M-Y, et al. Asymptomatic carrier state, acute respiratory disease, and pneumonia due to severe acute respiratory syndrome coronavirus 2 (SARS-CoV-2): Facts and myths. Journal of Microbiology, Immunology and Infection. 2020;53(3):404-12.doi: https://doi.org/10.1016/j.jmii.2020.02.012.

2. Acavut G, Pay RE, Ulubay M, Bozkurt ÖE. COVID-19 pandemisinin maternal-neonatal etkileri ve yönetimi. Türk Kadın Sağlığı ve Neonatoloji Dergisi. 2020;2(3):96-104.doi: https://doi.org/10.46969/ezh.757567.

3. Di Mascio D, Khalil A, Saccone G, Rizzo G, Buca D, Liberati M, et al. Outcome of coronavirus spectrum infections (SARS, MERS, COVID-19) during pregnancy: a systematic review and meta-analysis. American journal of obstetrics \& gynecology MFM. 2020;2(2):100107.doi: https://doi.org/10.1016/j.ajogmf.2020.100107.

4. Dashraath P, Wong JLJ, Lim MXK, Lim LM, LiS, Biswas A, et al. Coronavirus disease 2019 (COVID-19) pandemic and pregnancy. American journal of obstetrics and gynecology. 2020;222(6):521-31.doi: https://doi.org/10.1016/j.ajog.2020.03.021.

5. Sharma JB, Sharma E, Sharma S, Singh J. Recommendations for prenatal, intrapartum, and postpartum care during COVID-19 pandemic in India. American Journal of Reproductive Immunology. 2020;84(5):e13336.doi: https://doi. org/10.1111/aji.13336.

6. Şen Aytekin M, Yılar Erkek Z, Kahraman A. COVID-19 pandemisinde gebenin, yenidoğanın ve sağlık personelinin travayda korunmasına yönelik ebelik bakımı. Ebelik ve Sağlık Bilimleri Dergisi. 2021;4(2):176-88. 
7. Lin C, Chu S-M, Hsu J-F, Hsu C-C, Chang Y-L, Lien R, et al. Delivery management of suspected or confirmed COVID-19 positive mothers. Pediatrics \& Neonatology. 2021.doi: https://doi.org/10.1016/j.pedneo.2021.06.004.

8. Kotlar B, Gerson E, Petrillo S, Langer A, Tiemeier H. The impact of the COVID-19 pandemic on maternal and perinatal health: a scoping review. Reproductive Health. 2021;18(1):1-39.doi: https://doi.org/10.21203/rs.3.rs-96736/v1.

9. Riley T, Sully E, Ahmed Z, Biddlecom A. Estimates of the potential impact of the COVID-19 pandemic on sexual and reproductive health in low-and middle-income countries. International Perspectives on Sexual and Reproductive Health. 2020;46:73-6.doi: https://doi.org/10.1363/46e9020.

10. Işık G, Yeşilçınar I, Çetin Avcu S, Topaloğulu Ören ED, Evrenol Öçal S, Egelioğlu Çetişli N. COVID-19 enfeksiyonunun antenatal, intrapartum ve postpartum yönetimi. İzmir Katip Çelebi Üniversitesi Sağlık Bilimleri Fakültesi Dergisi. 2020;5(2):938.

11. Royal College of Obstetricians and Gyneacologist. COVID-19 virus infection and Pregnancy. Occupational health advice for employers and pregnant women during the COVID-19 pandemic 2020 [Available from: https://www.rcog.org.uk/en/ guidelines-research-services/.

12. Qi H, Chen M, Luo X, Liu X, Shi Y, Liu T, et al. Management of a delivery suite during the COVID-19 epidemic. European Journal of Obstetrics \& Gynecology and Reproductive Biology. 2020;250:250-2.doi: https://doi.org/10.1016/j. ejogrb.2020.05.031.

13. Boelig RC, Lambert C, Pena JA, Stone J, Bernstein PS, Berghella V, editors. Obstetric protocols in the setting of a pandemic. Seminars in Perinatology; 2020: Elsevier.

14. American College of Obstetricians and Gynecologists. COVID-19 FAQs for Obstetrician-Gynecologists, Obstetrics 2021 [Available from: https://www.acog.org/clinical-information/physician-faqs/covid-19-faqs-for-ob-gyns-obstetrics.

15. T.C. Sağlık Bakanlığı. COVID-19 (SARS-CoV-2 enfeksiyonu) solunum sistemi hastalıklarının yaygın olduğu dönemde sağlık kuruluşlarında gebe takibi 2021 [Available from: https://covid19.saglik.gov.tr/Eklenti/41676/0/covid-19solunumsistemihast aliklarininyayginoldugudonemdesaglikkuruluslarindagebetakibipdf.pdf.

16. World Health Organization. What we know about Breastfeeding and newborn care in the context of COVID-19 2020 [Available from: https://www.who.int/docs/default-source/coronaviruse/risk-comms-updates/update38-covid-19breastfeeding-and-newborn-care.pdf?sfvrsn=b64a0f4d_11\&download=true.

17. World Health Organization. Pregnancy and childbirth during COVID-19 2021 [Available from: https://www.who.int/ pmnch/covid-19/toolkits/maternal-newborn/pregnancy-childbirth/en/.

18. Centers for Disease Control and Prevention. Pregnant and Recently Pregnant People at Increased Risk for Severe IIIness from COVID-19 2021 [Available from: https://www.cdc.gov/coronavirus/2019-ncov/need-extra-precautions/pregnantpeople.htmI\#: :text=Top\%20of\%20Page-,Effect\%20on\%20Pregnancy\%200utcomes, without\%20COVID\%2D19\%20 during\%20pregnancy.

19. Rocca-Ihenacho L, Alonso C. Where do women birth during a pandemic? Changing perspectives on Safe Motherhood during the COVID-19 pandemic. Journal of Global Health Science. 2020;2(e4).doi: https://doi.org/10.35500/jghs.2020.2.e4.

20. Hermann A, Fitelson EM, Bergink V. Meeting maternal mental health needs during the COVID-19 pandemic. JAMA psychiatry. 2021;78(2):123-4.doi: https://doi.org/10.1001/jamapsychiatry.2020.1947.

21. Berghella V, Hughes B. COVID-19: Pregnancy issues and antenatal care. In: Post T, editor. UpToDate. Waltham, 2021.

22. Young BE, Ong SWX, Kalimuddin S, Low JG, Tan SY, Loh J, et al. Epidemiologic features and clinical course of patients infected with SARS-CoV-2 in Singapore. Jama. 2020;323(15):1488-94.doi: https://doi.org/10.1001/jama.2020.3204.

23. Cheema R, Partridge E, Kair LR, Kuhn-Riordon KM, Silva Al, Bettinelli ME, et al. Protecting breastfeeding during the COVID-19 pandemic. American journal of perinatology. 2020.doi: https://doi.org/10.1542/ppe_document201.

24. Oliveira CEdS, Moura MÁP, Dantas ALB, Gouveia MTdO, Mascarenhas VHA. Assistance for newborns in the delivery room during the COVID-19 pandemic. Acta Paulista de Enfermagem. 2021;34:1-9.doi: https://doi.org/10.37689/actape/2021AR03043.

25. Çevik E, Yanıkkerem E. İntrapartum dönemde kanıta dayalı uygulamalar doğrultusunda destekleyici hemşirelik bakımı. 2021. 189-203 p. 